\title{
Responsibility of microzooplankton and parasite pressure for the demise of toxic dinoflagellate blooms
}

\author{
David J. S. Montagnes ${ }^{1, *}$, Aurélie Chambouvet ${ }^{2,3}$, Laure Guillou $^{2,3}$, Andy Fenton ${ }^{1}$ \\ ${ }^{1}$ School of Biological Sciences, University of Liverpool, Biosciences Building, Crown Street, Liverpool L69 7ZB, UK \\ ${ }^{2}$ Université Pierre et Marie Curie - Paris 6, Station Biologique de Roscoff, Place Georges Teissier, BP 74, \\ 29680 Roscoff, France \\ ${ }^{3}$ CNRS, UMR 7144, Laboratoire Adaptation et Diversité en Milieu Marin, Place Georges Teissier, BP 74, \\ 29680 Roscoff, France
}

\begin{abstract}
Two mechanisms proposed to control dinoflagellate blooms - parasitism by eukaryotes (e.g. Amoebophrya sp.) and grazing by microzooplankton - have been explored through previous laboratory and field studies but lack quantitative assessment. We modelled the relative effect of these mechanisms. We used literature values to embed an Anderson-May host-microparasite model into a microbial food web model (nano- and microphytoplankton, nano- and microzooplankton, a toxic dinoflagellate, a dinoflagellate parasite). Three scenarios were examined to simulate the introduction of a toxic dinoflagellate and its parasite into an environment: (1) a food web, including autotrophic nanoand microplankton, heterotrophic flagellates, and ciliates; (2) as for Case 1 but with a toxic dinoflagellate; (3) as for Case 2 but with a dinoparasite. This mimics observations in a French estuary, where a toxic dinoflagellate began blooming in 1988; since 1998, blooms appear to have become regulated, and numerous parasitic infections by Amoebophrya sp. occurred from 2004 to 2006. After supporting parasite control of dinoflagellate blooms, we assessed the effects of observed ranges of key variables associated with the parasite and other components of the food web on parasite control of the dinoflagellate population. Population dynamics were examined over $50 \mathrm{~d}$. In Case 1, all taxa had 10 to $20 \mathrm{~d}$ blooms. In Case 2, the toxic dinoflagellate population dynamics mimicked that of the microphytoplankton, and this dinoflagellate was reduced in numbers but not extirpated by microzooplankton grazing. In Case 3 population blooms occurred, and the parasite virtually eliminated the dinoflagellate over $\sim 10 \mathrm{~d}$. Sensitivity analysis indicated that our assessment was robust. We propose that the decline in toxic dinoflagellates in the French estuary may have been due to an introduced dinoparasite. In general, we suggest that parasites may have greater impact on toxic dinoflagellate blooms than microzooplankton grazers; the parasites have the potential to eliminate the toxic dinoflagellates. We recommend that such parasites be incorporated into more complex food web models.
\end{abstract}

KEY WORDS: Amoebophrya - Alexandrium minutum - Dinospore - Harmful algal bloom · HAB . Microbial food web $\cdot$ Model $\cdot$ Plankton $\cdot$ Red tide

\section{INTRODUCTION}

The economic and societal impacts of harmful algal blooms (HABs) continue to motivate the study of HAB population dynamics and methods for their control. As one of the main HAB taxa, dinoflagellates have received considerable attention, and a substantial body of work exists describing the initiation, demise, and impact of their blooms (e.g. Shumway 1990, Donaghay \& Osborn 1997, Smayda 1997, Turner \& Tester 1997, Burkholder 1998, Anderson et al. 2002, Nagasaki et al. 2006). Two mechanisms proposed to control dinoflagellate blooms are parasitism by other eukaryotes (Coats et al. 1996), such as the dinoflagellate 
Amoebophrya sp. (Fig. 1), and grazing by microzooplankton, such as ciliates (e.g. Calbet et al. 2003, Rosetta \& McManus 2003). Although both of these mechanisms have been explored through laboratory and field studies, they lack quantitative assessment. We provide a critical first step toward modelling the relative impact of these 2 potential controlling pressures on toxic dinoflagellate populations.

Our analysis was in part stimulated by historical data on the HAB dinoflagellate Alexandrium minutum from 2 sources. First, data from East Harbour, Alexandria, Egypt, show that this species routinely bloomed from the 1970 s to $1990 \mathrm{~s}$, then blooms ceased, and this was attributed to removal of benthic cysts by hydrodynam-
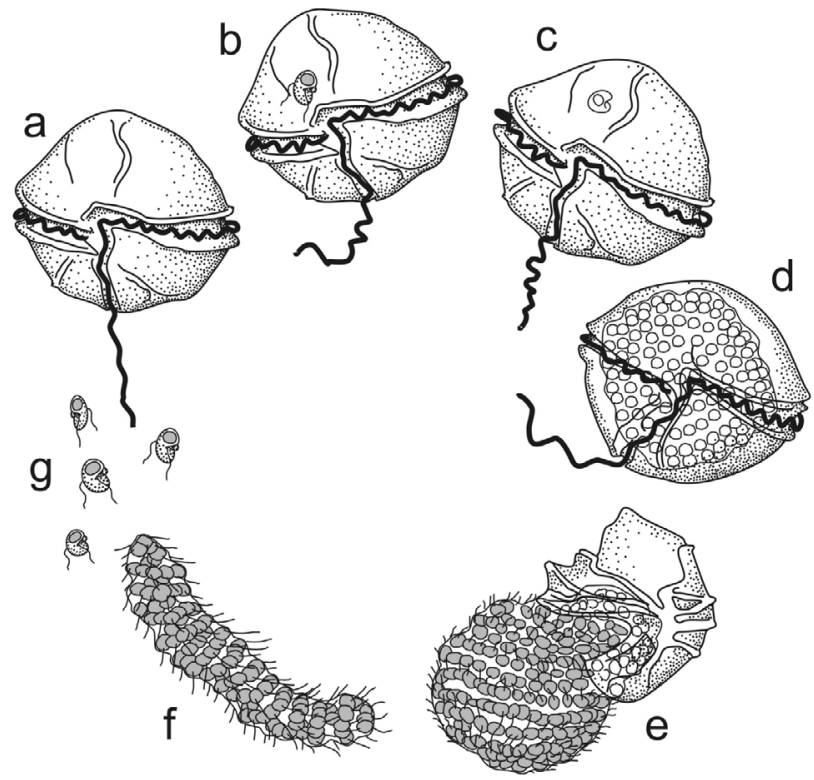

Fig. 1. Amoebophrya. This parasitic dinoflagellate, which infects (a) free-living dinoflagellates, has a relatively simple life cycle, consisting of (b) a dinospore, the infective dispersal stage (shown attached to dinoflagellate), (c) an intracellular trophont, (d) a growth stage, $(\mathrm{e}, \mathrm{f})$ an extracellular vermiform (a dispersal stage), and (g) individual motile dinospore cells (Cachon 1964, Cachon \& Cachon 1987). Dinospores are $\sim 10 \mu \mathrm{m}$ long, biflagellate cells that attach to the host surface, penetrate the host pellicle, and develop into trophonts in the cytoplasm or in the host nucleus, depending on the infected species (Cachon 1964, Park et al. 2002). The trophont grows in the host for $\sim 2 \mathrm{~d}$ (Coats et al. 1994, Yih \& Coats 2000) and replicates to produce a multinucleate, multiflagellate stage. At maturity, the multiflagellated stage metamorphoses into the vermiform, which escapes from the host, killing it. Vermiforms are free living for a fraction of a day (Coats \& Park 2002), and then undergo cytokinesis to produce hundreds to thousands of dinospores (Coats et al. 1994). Survival of dinospores outside the host is on the order of 1 to $2 \mathrm{~d}$ (Coats \& Park 2002). Mortality of the parasite occurs through predation, either on the infected host by grazers such as large microzooplankton (e.g. ciliates) or by grazing of dinospores by large nanozooplankton or smaller microzooplankton (e.g. heterotrophic flagellates) (Fig. 3) ically forced erosion (Ismael \& Khadr 2003), but we speculate that this could have been by biological control (see below). Second, A. minutum also occurs in northern France (Maguer et al. 2004), especially in the Penzé estuary and the Bay of Morlaix, Finistère, where it was first seen to form blooms $\left(>10^{6}\right.$ cells $\left.\mathrm{l}^{-1}\right)$ in 1988 , suggesting that it had recently been introduced to the region. As A. minutum forms resistant, resting cysts, populations became established permanently in shallow waters. However, although A. minutum blooms develop in this region with a predictable regularity each year in June (Maguer et al. 2004), maximal annual abundance has been decreasing since 1998 (Fig. 2), suggesting that the species is now being controlled. During A. minutum proliferations in the Penzé estuary between 2004 and 2007, the parasitic dinoflagellate Amoebophrya was detected by fluorescent in situ hybridization (using a general probe for the whole group); presence of this parasite appeared to be directly linked to the abrupt decline of A. minutum during the 3 consecutive years (A. Chambouvet unpubl. data). These data stimulated propositions that: (1) A. minutum was introduced to the system in the late $1980 s_{;}(2)$ during the 1990s A. minutum blooms were not controlled, or poorly controlled by grazing; and (3) in the late 1990s, the dinoflagellate parasite Amoebophrya entered the system and has subsequently controlled blooms. We suggest that a similar sequence of

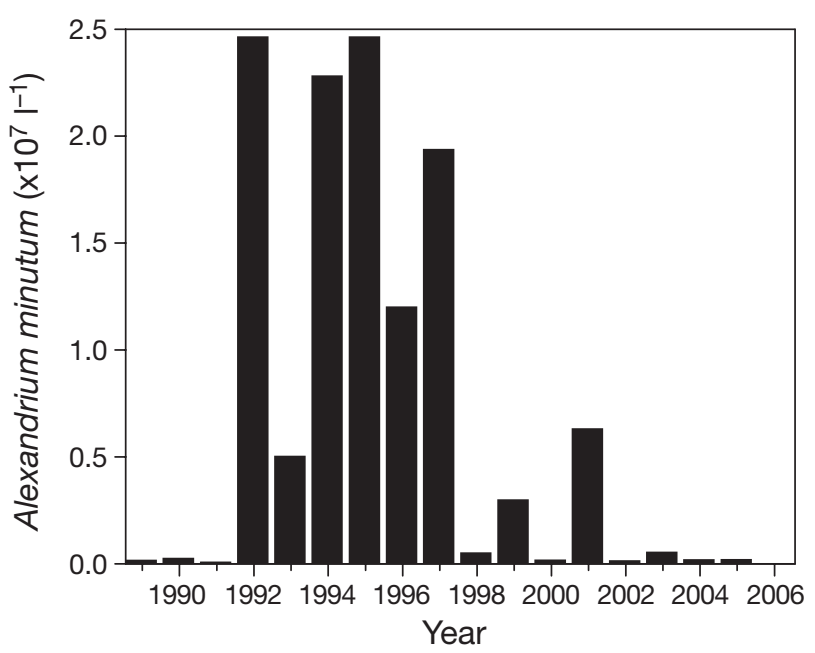

Fig. 2. Alexandrium minutum. Historical data on mean maximum annual abundance in the closely associated Penzé estuary and Bay of Morlaix, Finistère, France between 1988 and 2006, indicating the appearance of blooms and their subsequent decline. Note, data between 1988 and 1993 include observations from the Bay of Morlaix and from the Penzé estuary, and data for 2004 to 2006 include observations from only the Penzé estuary. Historical data from 1988 to 2003 were obtained from IFREMER (available at: www.ifremer.fr/envlit/ surveillance/telechargement.htm). Data from 2004 to 2006 are unpublished and have been archived by L. Guillou 
events may have occurred in East Harbour. However, we have neither established that the parasite can directly cause the decrease of the host populations in situ, nor can we unequivocally indicate that the parasite did not exist when $A$. minutum blooms were greatest in the 1990s. Nevertheless, based on a parameterised mathematical model, we can hypothesise that Amoebophrya (as opposed to grazing) can cause the demise of $A$. minutum blooms. Developing such a model is the first step towards a better understanding of the parasite-host population dynamics, which in turn may elucidate how such blooms are controlled in general.

Specifically, using existing literature parameters we have embedded a classical host-micro-parasite model (Anderson \& May 1980, 1981) into the microbial food web (Fig. 3) to evaluate the relative roles of parasites and grazers in the control of dinoflagellate blooms over a short period ( $<50 \mathrm{~d}$ ). Following our observations from the Finistère data, 3 progressive scenarios were examined to simulate the introduction of a toxic dinoflagellate and, subsequently, a dinoflagellate parasite into a marine environment: (1) a food web including only autotrophic nano- and microplankton, hererotrophic flagellates, and ciliates (groups that are typical of most microbial food webs); (2) as for Case 1, but with the introduction of a toxic dinoflagellate; and (3) as for Case 2, but with the addition of the parasite. After modelling indicated that the parasite (rather than

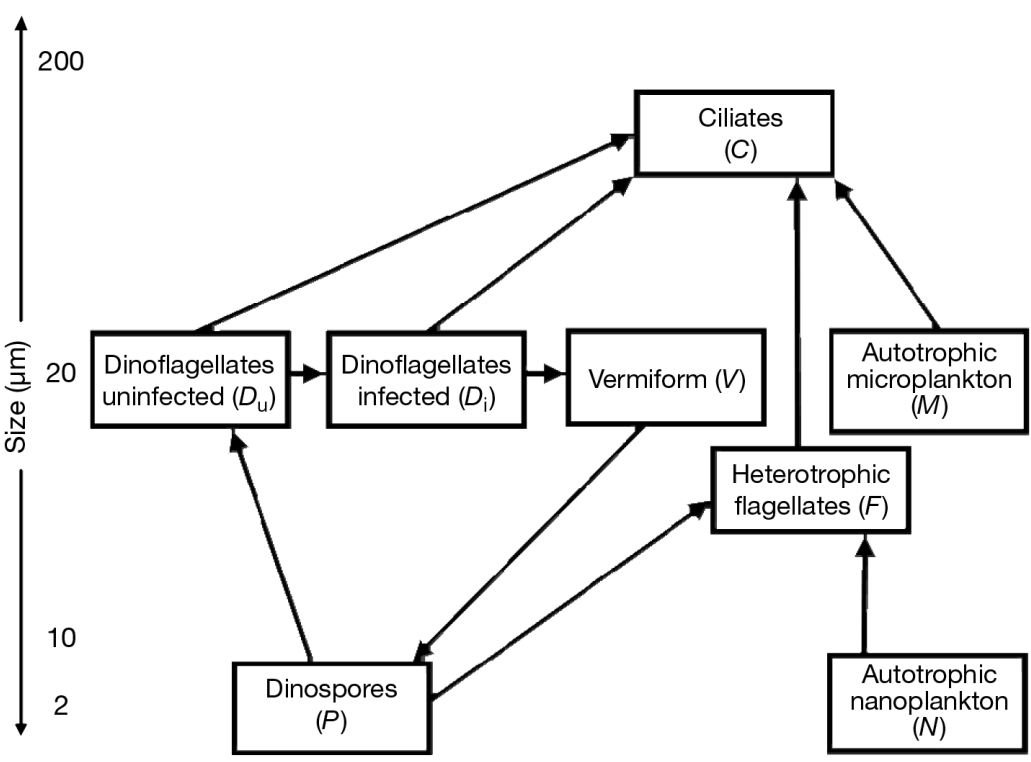

Fig. 3. The microbial food web investigated with the model included: ciliates $(C$, representing microzooplankton) as the top grazers on autotrophic microplankton $(M)$, heterotrophic flagellates $(F$, representing large nanozooplankton and small microzooplankton), dinoflagellates ( $D_{\mathrm{u}}$ : uninfected; $D_{\mathrm{i}}$ : infected), parasites as dinospores $(P)$ and vermiform $(V)$ stages, and autotrophic nanoplankton $(N)$. Note, arrows denote the flow of prey to consumer. Also note that the vermiform stage produces dinospores. The size scale on the left is an indication of organism size, with the smallest organism near the bottom microzooplankton) may control dinoflagellate blooms, we first conducted a sensitivity analysis to assess the impacts of the observed ranges of key parasite parameters on parasite control of the dinoflagellate population. We then explored, again through sensitivity analysis, whether changing other key parameters and state variables in the system would alter the bloom dynamics of parasites and their dinoflagellate host. Through these analyses we strongly suggest that parasite control of dinoflagellates may occur.

\section{METHODS}

Model description. Overview: We adopted a standard population-dynamic modelling framework to describe the changes in abundance of the following components of the eukaryotic microbial community (Fig. 3): large ciliates $(C)$, representing microzooplankton, as top-down control in the system; a HAB dinoflagellate $(D)$, as the host of the parasite and prey for the ciliate; autotrophic microplankton $(M)$, as an alternative prey pool for the ciliate; heterotrophic flagellates $(F)$, as top down control on both dinospores (i.e. the free-living stage of the parasite, $P$ ) and the vermiform (dispersal) stage $(V)$ of the parasite; and autotrophic nanoplankton $(N)$, as an alternative food for heterotrophic flagellates. For this exploratory simulation of population dynamics, the food web was assumed to be in a uniform physical environment at $18^{\circ} \mathrm{C}$ (unless otherwise stated, all parameter values in Table 1 were obtained at this temperature) and without immigration or emigration. Carrying capacities $(K)$ were imposed on the primary producers (resulting in logistic growth) to represent the impact of bottom-up nutrient control, whereby the strength of density dependence was assumed to depend on the sum of uninfected and infected dinoflagellates, microplankton, and nanoplankton $\left(D_{\mathrm{u}}+D_{\mathrm{i}}+M+N / 1000\right)$ populations (see Appendix 1).

In many population models based on the original Lotka-Volterra predatorprey models, the numerical response of the predator is determined from their functional response (assuming constant growth efficiency and metabolic loss rate; Turchin 2003), because direct measurements of growth rates are not available. However, for planktonic protozoa, there is a growing body of studies that provides direct measurements of both the functional and numerical responses within a single study of a single species 
(e.g. Montagnes 1996, Kamiyama 1997, Jeong et al. 1999, Montagnes \& Lessard 1999, Gismervik 2005, Kimmance et al. 2006). These measurements in turn provide the opportunity to directly combine functional and numerical responses in models, without the need to obtain independent estimates of assimilation rates or metabolic losses from the literature (e.g. Kamiyama 1997, Montagnes \& Lessard 1999, Kimmance et al 2006). In fact such models have already been applied to examine the impact of the tintinnid Favella taraikaensis on the dinoflagellate Alexandrium tamarense (Kamiyama 1997). This modelling framework is similar to that of the more traditional Lotka-Volterra-style models described above, but the latter formulation makes parameterisation easier from direct measurements of functional and numerical responses. We have, therefore, adopted this latter approach and used coupled predator functional and numerical responses for both the nano- and microzooplankton. Details on the specific food web components follow below and are presented in Table 1.

Dinoflagellate $(D)$ and dinoparasite $(P)$ : The generic dinoflagellate component of the model was parame- terised primarily from data on Alexandrium minutum. Dinoflagellate growth was assumed to be logistic, with a maximum specific growth rate $\left(r_{\mathrm{d}}\right)$ and carrying capacity $\left(K_{\mathrm{d}}\right)$. Dinoflagellates were assumed to die following infection by the free-living infective stages of the parasite (see $P$, below) and grazing by the ciliate (see 'Ciliates $[C]$ ', below).

The generic parasite component was based primarily on data for Amoebophrya sp. The host-parasite model was structured on the Anderson-May microparasite model (Anderson \& May 1980, 1981), wherein the dinoflagellate host population is divided into 2 compartments: uninfected $\left(D_{\mathrm{u}}\right)$ and infected $\left(D_{\mathrm{i}}\right)$ individuals, and comprises 4 coupled differential equations:

$$
\begin{aligned}
\frac{\mathrm{d} D_{\mathrm{u}}}{\mathrm{d} t} & =r_{\mathrm{d}} D_{\mathrm{u}}\left(1-\frac{D_{\mathrm{u}}+D_{\mathrm{i}}+M+N / 1000}{K_{\mathrm{d}}}\right)-D_{\mathrm{u}}\left(\beta P+C I_{\mathrm{c}}\right) \\
\frac{\mathrm{d} D_{\mathrm{i}}}{\mathrm{d} t} & =\beta P D_{\mathrm{u}}-D_{\mathrm{i}}\left(\alpha+C I_{\mathrm{c}}\right) \\
\frac{\mathrm{d} V}{\mathrm{~d} t} & =\alpha D_{\mathrm{i}}-\alpha^{\prime} V \\
\frac{\mathrm{d} P}{\mathrm{~d} t} & =\lambda \alpha^{\prime} V-P\left(r_{\mathrm{p}}+F I_{\mathrm{f}}\right)
\end{aligned}
$$

\begin{tabular}{|c|c|c|c|c|}
\hline Parameter/state variable & Symbol & Value & Unit & Source \\
\hline \multicolumn{5}{|l|}{ Dinoflagellate $(D)$} \\
\hline Carrying capacity & $K_{\mathrm{d}}$ & $3 \times 10^{6}$ & $D 1^{-1}$ & See Appendix 1 \\
\hline Maximum growth rate & $r_{\mathrm{d}}$ & 0.4 & $\mathrm{~d}^{-1}$ & Flynn et al. (1996) \\
\hline Mortality rate due to infection & $\alpha$ & $0.5(0.35-0.6)$ & $\mathrm{d}^{-1}$ & Coats \& Park (2002) \\
\hline Initial uninfected abundance & $D_{\mathrm{u}}$ & $5 \times 10^{3}\left(0.5-10 \times 10^{3}\right)$ & $D l^{-1}$ & Raymont (1980) \\
\hline Initial infected abundance & $D_{\mathrm{i}}$ & 0 & $D 1^{-1}$ & \\
\hline \multicolumn{5}{|l|}{ Parasite $(P)$} \\
\hline Development rate & $\alpha^{\prime}$ & $3(2-4)$ & $\mathrm{d}^{-1}$ & Coats \& Park (2002) \\
\hline Number released per host & $\lambda$ & $200(100$ to 400$)$ & $P D^{-1}$ & Yih \& Coats (2000) \\
\hline Mortality rate & $r_{\mathrm{p}}$ & $-0.55(-0.87$ to -0.23$)$ & $\mathrm{d}^{-1}$ & Coats \& Park (2002) \\
\hline Transmission rate $\left(\times 10^{-7}\right)$ & $\beta$ & $4(1-7)$ & $d^{-1} l^{-1}$ & See Appendix 1 \\
\hline Initial abundance & $P_{0}$ & 50 & $P 1^{-1}$ & None \\
\hline \multicolumn{5}{|l|}{ Nanoplankton $(N)$} \\
\hline Maximum growth rate & $r_{\mathrm{n}}$ & 1.0 & $\mathrm{~d}^{-1}$ & Furnas (1982) \\
\hline Carrying capacity & $K_{\mathrm{n}}$ & $3 \times 10^{9}$ & $N \mathrm{l}^{-1}$ & See Appendix 1 \\
\hline Initial abundance & $N_{0}$ & $10^{6}$ & $N \mathrm{l}^{-1}$ & Raymont (1980) \\
\hline \multicolumn{5}{|l|}{ Heterotrophic flagellates $(F)$} \\
\hline Growth rate & $r_{\mathrm{f}}$ & See Eq. (7) (text) & $\mathrm{d}^{-1}$ & Kimmance et al. (2006) \\
\hline Grazing rate & $I_{\mathrm{f}}$ & See Eq. (8) (text) & prey $F^{-1} \mathrm{~d}^{-1}$ & Kimmance et al. (2006) \\
\hline Initial abundance & $F_{0}$ & $5 \times 10^{3}$ & $F \mathrm{l}^{-1}$ & Gasol (1994) \\
\hline \multicolumn{5}{|l|}{ Microplankton $(M)$} \\
\hline Maximum growth rate & $r_{\mathrm{m}}$ & 0.4 & $\mathrm{~d}^{-1}$ & Bissinger et al. (2008) \\
\hline Carrying capacity & $K_{\mathrm{m}}$ & $3 \times 10^{6}$ & $M \mathrm{l}^{-1}$ & See Appendix 1 \\
\hline Initial abundance & $M_{0}$ & $10^{4}\left(0.5-50 \times 10^{3}\right)$ & $M \mathrm{l}^{-1}$ & Raymont (1980) \\
\hline \multicolumn{5}{|l|}{ Ciliate $(C)$} \\
\hline Growth rate & $r_{\mathrm{C}}$ & See Eq. (11) (text) & $\mathrm{d}^{-1}$ & Montagnes \& Lessard (1999) \\
\hline Grazing rate & $I_{\mathrm{C}}$ & See Eq. (12) (text) & prey $C^{-1} \mathrm{~d}^{-1}$ & Montagnes \& Lessard (1999) \\
\hline Initial abundance & $C_{0}$ & $10^{3}\left(0.1-10 \times 10^{3}\right)$ & $C \mathrm{l}^{-1}$ & Lynn \& Montagnes (1991) \\
\hline
\end{tabular}

Table 1. Model parameters and state variables. Further details of the derivation and origin of these are presented in Appendix 1. All rates were either collected at $\sim 18^{\circ} \mathrm{C}$ or have been temperature corrected, by applying a $Q_{10}$ of 2 . Values presented below were used in the 3 model-run case scenarios; ranges in parentheses were used in the sensitivity analysis 
where $\beta$ is the transmission rate, $I_{\mathrm{C}}$ is the ciliate grazing rate on dinoflagellates (see 'Ciliates $[C]$ ', below), $\alpha$ is the mortality rate due to infection, which imposes a time delay (of duration $1 / \alpha$ ) on the system, $r_{\mathrm{p}}$ is the parasite mortality rate, and $I_{\mathrm{f}}$ is the heterotrophic flagellate grazing rate on parasites (see 'Heterotrophic flagellates $[F]$ ', below). The model incorporates the free-living vermiform stage $(V)$ of the parasite, which lasts on average $1 / \alpha \mathrm{d}$ before undergoing cytokinesis to produce $\lambda$ dinospores $(P)$. We assumed that infected dinoflagellates die without reproducing (Elbrächter 1973, Cachon \& Cachon 1987), that dinoflagellates were only infected once, although multiple infections may occur (Coats \& Park 2002), and that dinoflagellate infection increased linearly with parasite abundance. Furthermore, $\beta$ was assumed not to decrease with dinospore age, although such a decrease can occur (Coats \& Park 2002); however, the variation in $\beta$ examined during our sensitivity analysis (see below) should compensate for these omissions.

Nanoplankton $(\boldsymbol{N})$ : The autotrophic nanoplankton provided prey for heterotrophic flagellates, allowing the latter to survive when there were no parasites. Nanoplankton growth was assumed to be logistic, with a maximum specific growth rate $\left(r_{n}\right)$, carrying capacity $\left(K_{\mathrm{n}}\right)$, and mortality caused by heterotrophic flagellate grazing (see 'Heterotrophic flagellates $[F]$ ', below). Nanoplankton dynamics were modelled as:

$$
\frac{\mathrm{d} N}{\mathrm{~d} t}=r_{\mathrm{n}} N\left(1-\frac{D_{\mathrm{i}}+D_{\mathrm{u}}+M+N / 1000}{K_{\mathrm{n}}}\right)-\frac{F I_{\mathrm{f}} N}{(N+P)}
$$

Note that nanoplankton were grazed by heterotrophic flagellates in proportion to abundance relative to the other component of the flagellate diet, i.e. dinospores of the parasite $(P)$.

Heterotrophic flagellates (F): Heterotrophic flagellates are grazers on dinospores and nanoplankton, and their population dynamics were modelled as:

$$
\frac{\mathrm{d} F}{\mathrm{~d} t}=r_{\mathrm{f}} F-C I_{C}
$$

where $I_{C}$ is ciliate grazing rate (see 'Ciliates $[C]$ ', below), and growth rate $\left(r_{\mathrm{f}}\right)$ was determined from a numerical response (growth rate versus prey concentration) that includes a threshold prey concentration $\left(6393 \mathrm{ml}^{-1}\right)$, below which growth rate becomes negative (Kimmance et al. 2006):

$$
r_{\mathrm{f}}=\frac{0.94 \times(P+N-6393)}{14160+(P+N-6393)} \times 0.05 T
$$

where $T$ is temperature $\left({ }^{\circ} \mathrm{C}\right)$.

Heterotrophic flagellates grazed on nanoplankton and dinospores at a rate $\left(I_{\mathrm{f}}\right)$ that followed a temperature $(T)$ dependent functional response (Kimmance et al. 2006; note, hourly rates were converted to daily rates, assuming a constant rate over $24 \mathrm{~h}$ ):

$$
I_{\mathrm{f}}=\frac{23.74 \times(P+N)}{112010+P+N} \times 0.28(T-7.99)^{0.10} \times 24
$$

We assumed that there was no preference for either nanoplankton or dinospores, so heterotrophic flagellates consumed these prey at a rate proportional to their availability.

Microplankton (M): The autotrophic microplankton population provided a prey pool for ciliates, allowing them to grow when dinoflagellates and heterotrophic flagellates were rare. Microplankton population growth was assumed to be logistic, with a maximum specific growth rate $\left(r_{\mathrm{m}}\right)$ and carrying capacity $\left(K_{\mathrm{m}}\right)$. $r_{\mathrm{m}}$ was set to equal that of the dinoflagellate, so that unequal competition between these 2 autotrophs was not an issue in the control of dinoflagellate blooms. Microplankton mortality was caused only by ciliate grazing (see 'Ciliates $[C]^{\prime}$ ', below) at rate $I_{\mathrm{c}}$, and in proportion to microplankton abundance relative to the other components of the ciliate diet (dinoflagellates and heterotrophic flagellates). Hence, microplankton population growth was modelled as:

$\frac{\mathrm{d} M}{\mathrm{~d} t}=r_{m} M\left(1-\frac{D_{\mathrm{u}}+D_{\mathrm{i}}+M+N / 1000}{K_{\mathrm{m}}}\right)-\frac{C I_{c} M}{\left(D_{\mathrm{u}}+D_{\mathrm{i}}+M+F\right)}$

Ciliates (C): Ciliates grazed on autotrophic microplankton (including the dinoflagellates) and heterotrophic flagellates; their population growth was modelled as:

$$
\frac{\mathrm{d} C}{\mathrm{~d} t}=r_{\mathrm{c}} C
$$

where ciliate specific growth rate $\left(r_{c}\right)$ was based on a numerical response that includes a threshold prey concentration $\left(1308 \mathrm{ml}^{-1}\right)$, below which growth rate is negative (Montagnes \& Lessard 1999; note, these rates were established at $13^{\circ} \mathrm{C}$ and were temperature-corrected to $18^{\circ} \mathrm{C}$, assuming a $Q_{10}$ of 2, although this may not always be appropriate; see Montagnes et al. 2003):

$$
r_{\mathrm{C}}=\frac{0.622 \times\left(D_{\mathrm{u}}+D_{\mathrm{i}}+F+M-1308\right)}{2384+\left(D_{\mathrm{u}}+D_{\mathrm{i}}+F+M-1308\right)}
$$

$I_{\mathrm{C}}$ followed a functional response (Montagnes \& Lessard 1999; note, rates were temperature corrected, as for Eq. 11 above, and hourly rates were converted to daily rates, assuming grazing was constant over 24 h):

$I_{\mathrm{c}}=\frac{197}{1+19000 /\left(D_{\mathrm{u}}+D_{\mathrm{i}}+F+M\right)+\left(D_{\mathrm{u}}+D_{\mathrm{i}}+F+M\right) / 3314} \times 24$

Ciliate ingestion was then determined for each of the 4 potential prey $\left(D_{\mathrm{u}}, D_{\mathrm{i}}, F, M\right)$; assuming no preference, they were consumed as a proportion of the total prey available. 
Note that there are indications that ciliates may have reduced growth and grazing rates when exposed to some toxic dinoflagellates (e.g. Hansen 1986, Jeong et al. 1999, Rosetta \& McManus 2003). Here we are testing the potential maximum impact of microzooplankton grazing, in comparison with parasite-induced mortality. Therefore, we have not imposed an inhibition due to prey type.

Model simulations. Explored scenarios: Three distinct scenarios were examined to simulate the introduction of a toxic dinoflagellate and, subsequently, a parasite to an environment: (1) a simple food web, including only autotrophic nano- and microplankton, hererotrophic flagellates, and ciliates; (2) the food web described in Case 1, but with the introduction of a dinoflagellate; and (3) the food web described in Case 2, but with the addition of a specific parasite for the dinoflagellate introduced in Case 2. Runs of the model were conducted using parameters and state variables presented in Table 1, which are further justified in Appendix 1.

Sensitivity analysis: Our analysis indicated that the parasite has a greater impact than microzooplankton on dinoflagellate blooms (see 'Results'); consequently, our emphasis was directed to assessing the sensitivity of parameters associated with the parasite. After establishing that variation of these parameters failed to alter our results, we ran a further set of sensitivity analyses to assess whether other non-parasite parameters and state variables might alter the observed model outcome (i.e. parasite blooms cooccurring with the demise of dinoflagellate blooms, resulting in collapse of host populations; see 'Results').

We provide ranges for 5 of the parasite parameters used in the model as estimated from the literature (Table 1), but initial observations indicated that only 4 of these altered the model output to any extent: (1) mortality rate due to infection $(\alpha)_{i}(2)$ the number of parasites released per host $(\lambda)_{i}(3)$ parasite mortality rate $\left(r_{\mathrm{p}}\right)$; and (4) parasite transmission rate $(\beta)$. We investigated how variation of these parameters altered predictions of population dynamics over observed ranges (Table 1). We also examined variation in (1) initial abundances of dinoflagellates, ciliates, and microplankton (Table 1); (2) the carrying capacity for autotrophs ( $K$, which was altered from 0.1 to 3.0 times the value presented in Appendix 1);
(3) both ciliate growth rate and ingestion rate (at the same time; i.e. the two were altered simultaneously and equally over a range spanning 0.5 to 1.5 times the literature value, Eqs. 11 \& 12); (4) heterotrophic flagellate maximum growth rate and ingestion rate (concurrently, following the logic outlined above for ciliate parameters); (5) ciliate threshold concentration; and (6) heterotrophic flagellate threshold concentration (the prey concentration at which growth = 0 , which was altered over a range spanning 0.5 to 1.5 times the literature values, Eqs. 7 \& 11). For each parameter, model runs were conducted at 4 levels, evenly distributed across the range, from the lowest value to the highest value.

\section{RESULTS}

\section{Explored scenarios}

In Case 1 (Fig. 4a-f), in which there were no dinoflagellates or parasites, autotrophic microplankton bloomed over $\sim 30 \mathrm{~d}$ and then decreased due to grazing by ciliates, which bloomed after $\sim 30 \mathrm{~d}$; nanoplankton formed a bloom after $\sim 10 \mathrm{~d}$, which was controlled by heterotrophic flagellates, which bloomed after 15 d. In Case 2 (Fig. 4g-1), in which dinoflagellates were introduced, the population dynamics of all groups were similar to those in Case 1, but the microplankton population was depressed due to competition with the dinoflagellates; the dinoflagellate population mirrored the microplankton population dynamics (as expected, given their identical growth rates), except that dinoflagellate abundance was $\sim 0.5$ times lower than that of the microplankton, due to reduced initial dinoflagellate abundance. In Case 3 (Fig. 4m-r), in which parasites were included, population dynamics of most groups were the same as those in Case 1, except that there was a secondary, small population-pulse of heterotrophic flagellates after the initial bloom; this second pulse was due to a parasite bloom (i.e. a new prey for heterotrophic flagellates) at $\sim 20 \mathrm{~d}$ (Fig. 4r). Most importantly, the peak in abundance of the dinoflagellate in the presence of the parasite was around half that in parasite absence, and the bloom, which lasted $<30 \mathrm{~d}$, did not recover over the $50 \mathrm{~d}$ simulation (Fig. 4n).

Fig. 4. Output of population dynamics from our model food web (Fig. 3): (a,g,m) autotrophic microplankton; (b,h,n) total dinoflagellates; $(\mathrm{c}, \mathrm{i}, \mathrm{o})$ autotrophic nanoplankton; $(\mathrm{d}, \mathrm{j}, \mathrm{p})$ heterotrophic flagellates; $(\mathrm{e}, \mathrm{k}, \mathrm{q})$ ciliates; $(\mathrm{f}, \mathrm{l}, \mathrm{r})$ dinospore parasites. Three distinct scenarios (Cases 1, 2 and 3; see 'Results; Explored scenarios') were examined to simulate the introduction of a toxic dinoflagellate and its parasite to the environment. Runs of the model were conducted using parameters and state variables outlined in Table 1 
Case 1

Dinoflagellate absent Parasite absent
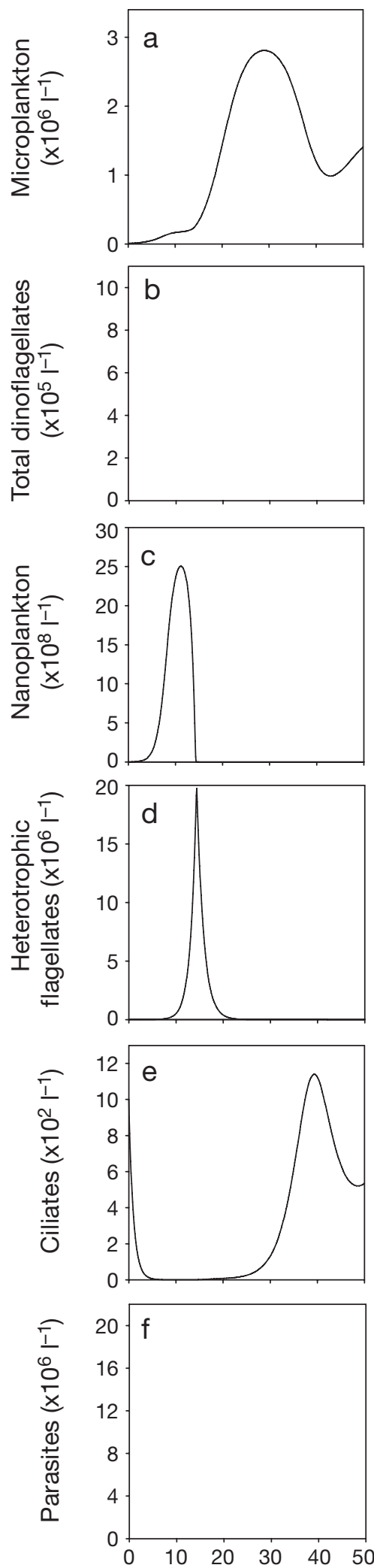

Case 2

Dinoflagellate present Parasite absent
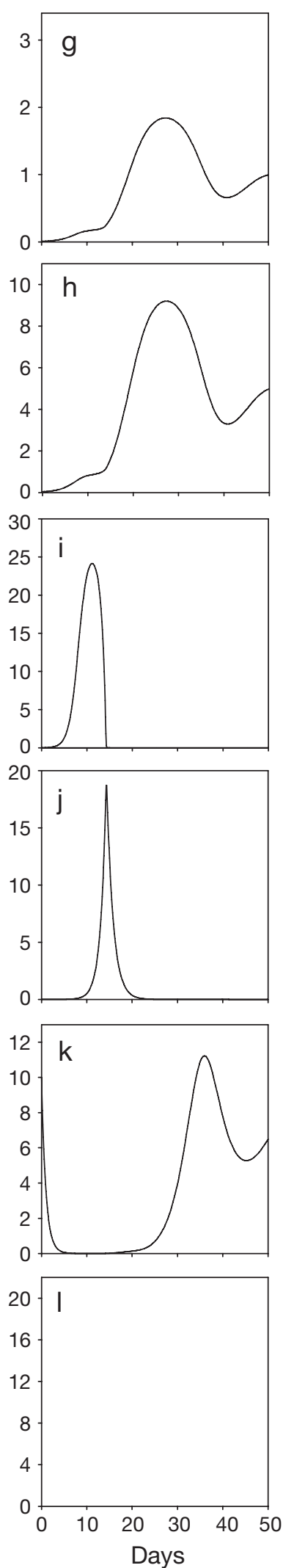

Case 3

Dinoflagellate present

Parasite present
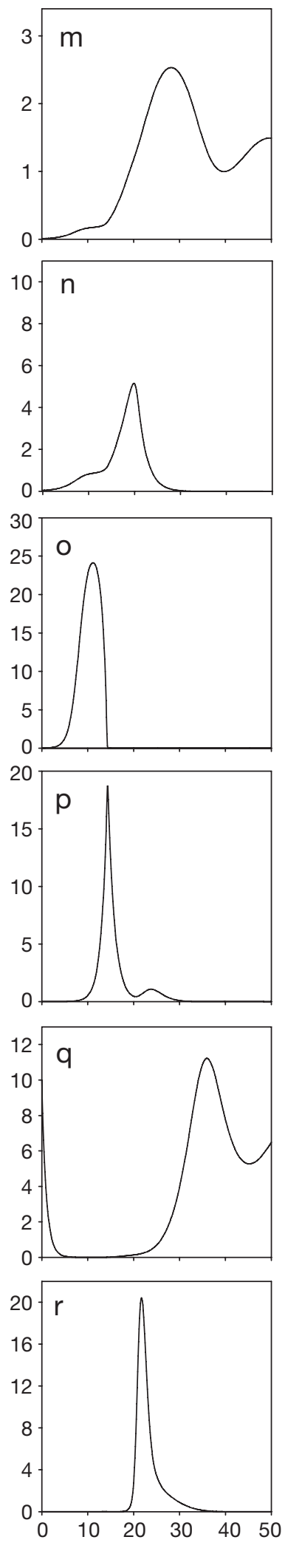


\section{Sensitivity analysis}

Potential variation (see Table 1) in dinoflagellate mortality rate due to infection $(\alpha)$, the number of dinospores released per host $(\lambda)$, parasite mortality rate $\left(r_{\mathrm{p}}\right)$, and parasite transmission rate $(\beta)$ revealed that under all conditions the parasite was able to control the dinoflagellate host population, exceeding that due to grazing by ciliates (cf. Figs. $4 \mathrm{~h} \& 5 \mathrm{~b}, \mathrm{~h}, \mathrm{n}, \mathrm{t}$ ). The main impacts of varying the above parameters were on peak abundance and persistence of dinoflagellates and the parasite, and this only occurred when $\lambda$ and $\beta$ were raised to their upper extent (Fig. 5h,l,t,x). None of the other components of the food web was substantially influenced by altering the above parameters, except for the autotrophic microplankton when they were competing with the dinoflagellate.

Variation in initial abundances of dinoflagellates, ciliates, and microphytoplankton, and the carrying capacity $(K)$ produced many differences in the population dynamics of the entire system (Fig. 6). However, the general pattern (as indicated above) that dinoflagellate blooms were immediately followed by parasite blooms was consistent, regardless of the perturbation. Furthermore, the demise of the dinoflagellates was directly attributable to parasite infection, not ciliate grazing (results of these details are not presented here but can be explored through contact with D. J. S. Montagnes). Potential variation in ciliate and heterotrophic flagellate growth and grazing parameters also revealed marked differences in population dynamics within the food web, but again, the general indication was that dinoflagellate blooms were controlled and followed by parasite blooms (Fig. 7). The main exception to this trend was for conditions in which the ciliate threshold (i.e. the prey concentration where $r_{\mathrm{C}}=0$ ) was reduced to 0.5 of the literature value; in this case, ciliates survived at low prey abundances, subsequently bloomed in response to raised dinoflagellate and microplankton abundances, and then controlled both these prey populations over the first $20 \mathrm{~d}$ (solid lines in Fig. $7 g, h, k)$. However, under this condition $(0.5$ of the ciliate threshold level), parasites controlled (and virtually removed) the dinoflagellates in the latter part of the $50 \mathrm{~d}$ simulation, supporting the pattern observed above for other conditions.

\section{DISCUSSION}

Using a microbial food web model, we explored 2 hypotheses proposed for the control of potentially toxic dinoflagellate blooms: microzooplankton grazing (Kamiyama 1997, Jeong et al. 1999, Rosetta \& McManus 2003) and parasite-induced mortality (Coats et al. 1996, Johansson \& Coats 2002). This is the first study to quantitatively test these combined hypotheses.

Here we examine, over a $50 \mathrm{~d}$ period, the consequences for harmful algal bloom dynamics within the microbial food web. Unlike many exploratory population models, this analysis limited the output to evaluation of $\sim 1$ cycle of the population dynamics (i.e. it would have been possible under some conditions to produce multiple population cycles, if the simulation time was extended beyond $50 \mathrm{~d}$ ). Our logic for not extending the simulation beyond $50 \mathrm{~d}$ was that both environmental (e.g. climatic) and biological (e.g. metazoan zooplankton) perturbations in pelagic systems would undoubtedly occur over a period longer than $50 \mathrm{~d}$ and would disturb the system; thus, we have not provided longer-term (and inappropriate) simulations. Furthermore, we specifically excluded metazoan zooplankton (e.g. copepods) for the following reasons. Firstly, the focus of this study was to assess whether components of the microbial food web alone could control toxic dinoflagellates, and secondly there is evidence to suggest that microzooplankton grazing will have greater effects than metazoan zooplankton grazing on toxic dinoflagellate bloom dynamics (Calbet et al. 2003). However, we also recognise that as metazoan zooplankton generation times (>10 d, e.g. Gillooly 2000) would not result in substantial zooplankton population fluctuations, the population dynamics of these metazoans and their impact would therefore be relatively constant. Such constant grazing pressures would simply increase prey mortality rates by a constant amount (i.e. result in lower estimates of $r_{\mathrm{d}}$ and $r_{\mathrm{m}}$ ). However, fast-growing smaller copepods might respond, and other modelling efforts have indicated that metazoan zooplankton grazing can control dinoflagellate blooms (Griffin et al. 2001, Gismervik et al. 2002), so this may be an area for further exploration. We have also not considered viruses, which may influence phytoplankton dynamics (Brussaard 2004), specifically that of dinoflagellates (Nagasaki et al. 2006). The influence of viruses has been included in models of plankton dynamics, with various results (e.g. Chattopadhyay \& Pal 2002, Singh et al. 2004). Again, omission of viruses allowed us to specifically evaluate the potential role of microzooplankton and eukaryotic parasites. Finally, although we applied well-established, non-linear functional and numerical responses for the grazers (based on the limited data available) we assumed a linear relationship between parasite infection and abundance; non linear dynamics might reduce the impact of parasites at high abundances. Clearly, now that our findings support the prediction of Coats et al. (1996) that parasite control is possible, and also show the extent to which these dinoflagellate parasites may alter bloom dynamics, we recommend that more com- 

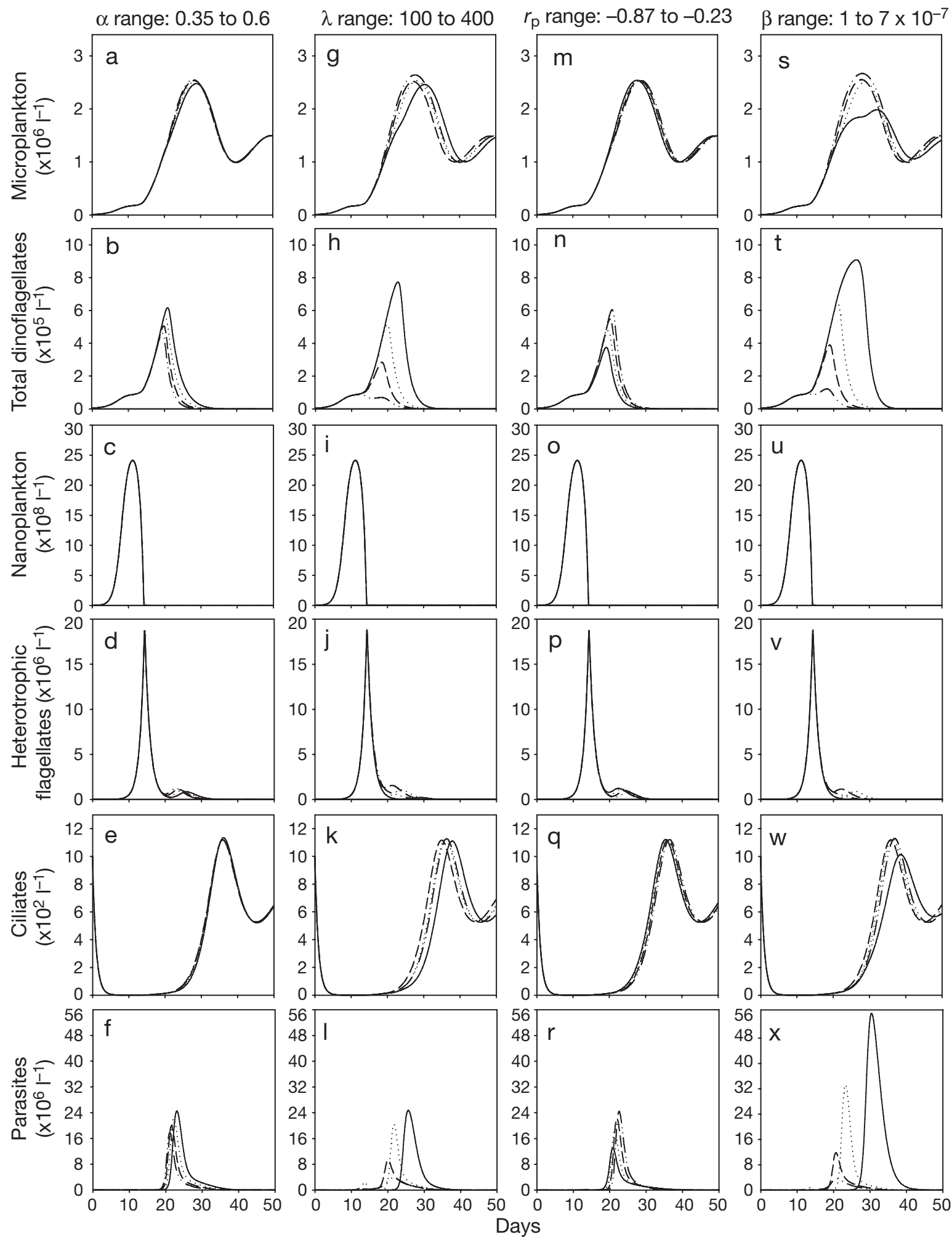

Fig. 5. Sensitivity analysis for effects of varying key parasite life-cycle parameters on population dynamics of our microbial food web (Fig. 3): $(\mathrm{a}, \mathrm{g}, \mathrm{m}, \mathrm{s})$ autotrophic microplankton; $(\mathrm{b}, \mathrm{h}, \mathrm{n}, \mathrm{t})$ total dinoflagellates; $(\mathrm{c}, \mathrm{i}, \mathrm{o}, \mathrm{u})$ autotrophic nanoplankton; $(\mathrm{d}, \mathrm{j}, \mathrm{p}, \mathrm{v}) \mathrm{het}-$ erotrophic flagellates; $(e, k, q, w)$ ciliates; $(f, l, r, x)$ dinospore parasites. Changes in population dynamics, within a panel (i.e. different line types) are the responses of estimates for 4 parasite parameters (Table 1$)$ : mortality rate due to infection ( $\alpha$; a-f); parasites released per host $(\lambda ; g-1)$; parasite mortality rate $\left(r_{\mathrm{p} ;} \mathrm{m}-\mathrm{r}\right)$; and parasite transmission rate $(\beta ; \mathrm{s}-\mathrm{x})$. For each parameter, model runs were conducted at 4 levels (line types), evenly distributed across the range, from the lowest value to the highest value (solid, dots, dashes, dots \& dashes, respectively) 

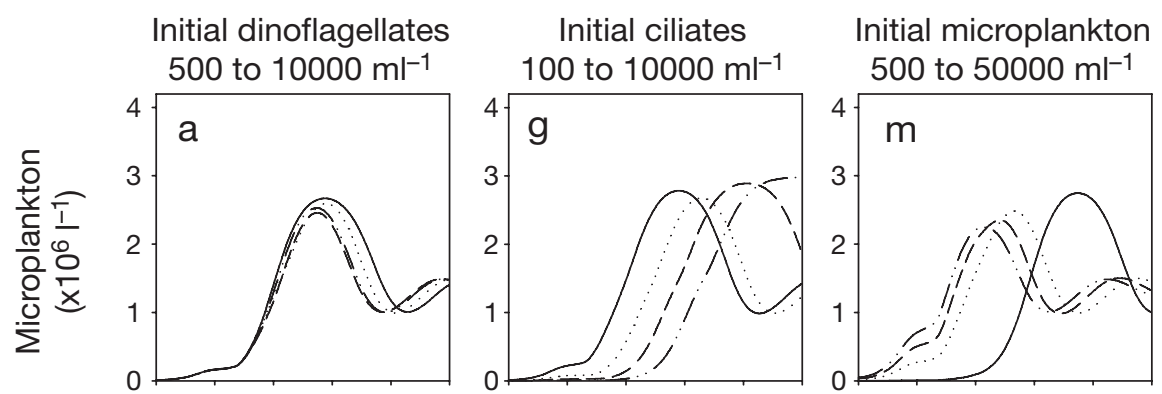

Carrying capacity $(K)$

500 to $50000 \mathrm{ml}^{-1}$

$0.1 \times K$ to $3 \times K$
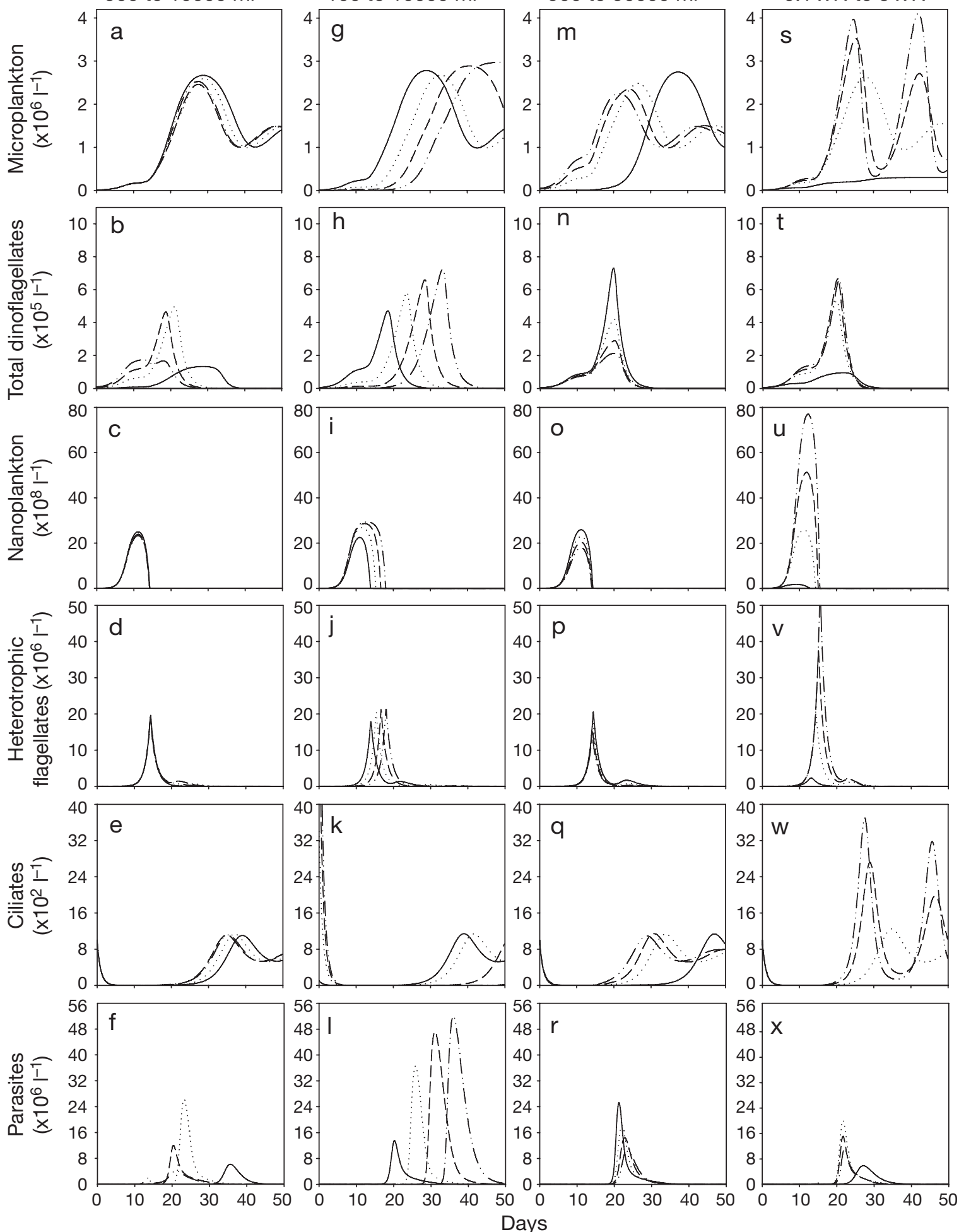

Fig. 6. Sensitivity analysis for effects of varying initial abundances of dinoflagellates $\left(D_{\mathrm{u}}\right)$, ciliates $(C)$ and microzooplankton $(M)$ and the combined carrying capacity $(K)$ of the autotrophs (see Appendix 1) on population dynamics of our microbial food web (Fig. 3): $(\mathrm{a}, \mathrm{g}, \mathrm{m}, \mathrm{s})$ autotrophic microplankton; $(\mathrm{b}, \mathrm{h}, \mathrm{n}, \mathrm{t})$ total dinoflagellates; $(\mathrm{c}, \mathrm{i}, \mathrm{o}, \mathrm{u})$ autotrophic nanoplankton; $(\mathrm{d}, \mathrm{j}, \mathrm{p}, \mathrm{v}) \mathrm{hetero-}$ trophic flagellates; $(\mathrm{e}, \mathrm{k}, \mathrm{q}, \mathrm{w})$ ciliates; $(\mathrm{f}, \mathrm{l}, \mathrm{r}, \mathrm{x})$ dinospore parasites. Changes in population dynamics, within a panel (i.e. different line types) are the responses of estimates for ranges presented in Table 1. For each parameter, model runs were conducted at 4 levels (line types), evenly distributed across the range, from the lowest value to the highest value (solid, dots, dashes, 

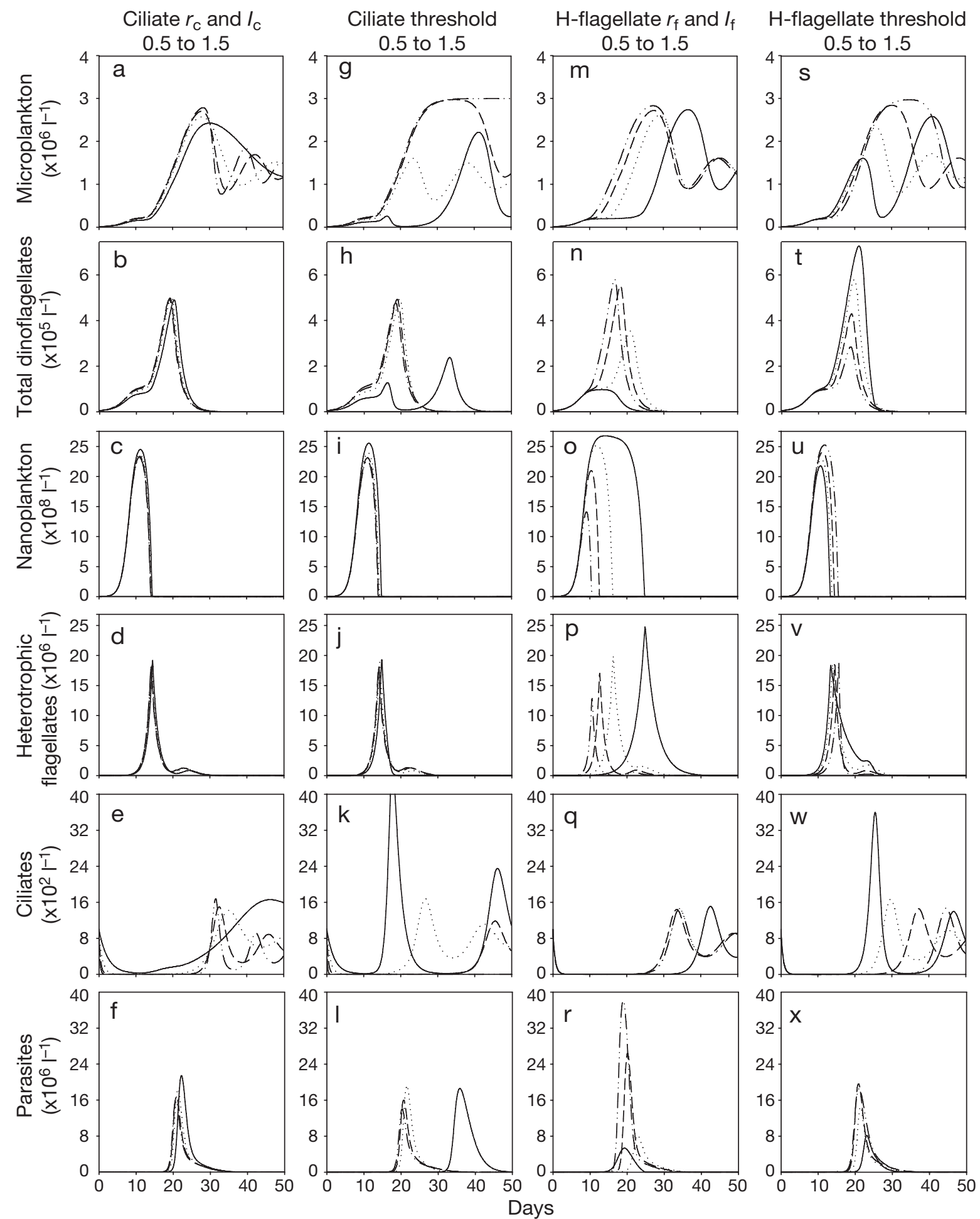

Fig. 7. Sensitivity analysis for effects of varying growth and grazing parameters of the ciliate and heterotrophic flagellate on population dynamics of our microbial food web (Fig. 3): (a,g,m,s) autotrophic microplankton; (b,h,n,t) total dinoflagellates; (c,i,o,u) autotrophic nanoplankton; $(\mathrm{d}, \mathrm{j}, \mathrm{p}, \mathrm{v})$ heterotrophic flagellates; $(\mathrm{e}, \mathrm{k}, \mathrm{q}, \mathrm{w})$ ciliates; $(\mathrm{f}, \mathrm{l}, \mathrm{r}, \mathrm{x})$ dinospore parasites. Changes in population dynamics, within a panel (i.e. different line types) are the responses of estimates for 4 parameters, or combined parameters: ciliate growth rate $r_{\mathrm{c}}$ and ingestion rate $I_{\mathrm{c}}$ were simultaneously altered between 0.5 and 1.5 of literature values (Table 1); ciliate threshold (the prey concentration where growth rate is zero) was varied between 0.5 and 1.5 of literature values (Eq. 11); heterotrophic flagellate growth rate $\left(r_{\mathrm{f}}\right)$ and ingestion rate $\left(I_{\mathrm{f}}\right)$ were simultaneously altered between 0.5 and 1.5 of literature values (Table 1); heterotrophic flagellate threshold was varied between 0.5 and 1.5 of literature values (Eq. 7). For each parameter, model runs were conducted at 4 levels (line types), evenly distributed across the range, from the lowest value to the highest value (solid, dots, dashes, dots \& dashes, respectively). H-flagellate: heterotrophic flagellate 
plex pelagic models extending over longer periods (e.g. that of Griffin et al. 2001) should include such eukaryotic parasites.

\section{Scenarios and sensitivity analysis}

In Case 1 (Fig. 4), we presented a scenario in which a body of water contains micro- and nanophytoplankton that are grazed by micro- and nanozooplankton, respectively. As can occur in nature, the autotrophic microplankton population was initially controlled by bottom-up pressure as they reached their carrying capacity, and then they were controlled by top-down microzooplankton grazing (e.g. Montagnes 1996, Glibert 1997, Strom 2002). Similarly, the autotrophic nanoplankton plankton was initially bottom-up controlled and then grazed by the nanozooplankton. The microzooplankton, which had no top-down control imposed on them, died due to starvation when prey resources dropped below their threshold level, and the nanozooplankton died from both starvation and microzooplankton grazing. Such short-term population dynamics have been described by others in field studies, laboratory studies, mesocosm experiments, and models (e.g. Stoecker \& Evans 1985, Andersen \& Sørensen 1986, Lynn \& Montagnes 1991, Montagnes \& Lessard 1999, Gismervik et al. 2002, Kimmance et al. 2006), with population levels and timing of events at a similar order of magnitude to those presented here (e.g. Raymont 1980, Andersen \& Sørensen 1986, Lynn \& Montagnes 1991). This congruence suggests that our initial scenario is not unrealistic. However, we recognise that there is a dearth of good data to validate our predictions, and we now strongly support further careful field, mesocosm, and microcosm monitoring to specifically assess our predictions on the occurrence and timing of these events related to parasitism.

In Case 2, we simulated the introduction of a HAB dinoflagellate into the model environment. Such introductions could be through direct human intervention (e.g. ballast water, Hallegraeff 1998), by natural dispersal, or by indirect anthropogenic dispersal induced by climate change (Gómez 2003). Regardless of the mechanism of introduction, we showed firstly that the dinoflagellate reached realistic bloom levels (e.g. Calbet et al. 2003) (as the autotrophs reached their combined carrying capacity), and secondly that the dinoflagellate was controlled, or at least reduced by microzooplankton (i.e. ciliate) grazing, as proposed by Rosetta \& McManus (2003) and Calbet et al. (2003). It should be noted that our model presupposes that the microzooplankton will consume toxic species, although such toxic species can reduce growth and grazing of ciliates (Kamiyama 1997, Jeong et al. 1999); our predictions, therefore, provide a maximum potential for microzooplankton control, and it may be lower in reality. Furthermore, the dinoflagellate population was never significantly reduced, suggesting that microzooplankton grazing pressure alone may not suffice to alleviate problems associated with toxic dinoflagellate blooms.

In contrast, in Case 3, in which a dinoflagellate parasite was introduced to the system, not only was the toxic dinoflagellate controlled, it was virtually eliminated from the system, supporting the argument of researchers such as Coats et al. (1996) that parasitism is important in the control of blooms; we also suggest that Alexandrium minutum may have been removed from both East Harbour, Alexandria, Egypt, and the Penzé estuary, France (see 'Introduction', Fig. 2) by parasite control, although this is clearly speculative. However, there will be parasite-specific variation in virulence, and there is both experimental and environmentally induced variation in virulence, even for a single parasite species (Table 1, Appendix 1). There will also be variation in parameters associated with the ciliate and heterotrophic flagellate growth and grazing responses, and the initial abundances and carrying capacity of the autotrophs may vary. We have, therefore, explored the robustness of our predictions by altering key parameters associated with the parasite biology (Fig. 5), the abundances and carrying capacity of the autotrophs (Fig. 6), and parameters associated with the predator responses (Fig. 7).

Importantly, altering parasite-related parameters had little effect on the various components of the food web, other than the dinoflagellate and the parasite. Furthermore, except by applying the extremes of the estimates of 2 factors, i.e. the number of parasites produced per host and transmission rate (Table 1), there was little impact of changing parameters on our initial predictions for Case 3; this supports our general conclusions even when considering the potential variation of the parasite. Moreover, although varying other aspects of the model impacted a number of components of population dynamics (Figs. 6 \& 7), there was a single overriding outcome: within the $50 \mathrm{~d}$ simulation, dinoflagellate blooms were closely followed by parasite blooms, with the parasite directly reducing the dinoflagellates almost to extirpation. Although there is clearly variation in the dynamics, these observations support our initial hypothesis that it is the parasite, and not grazing by microzooplankton, that can cause the demise of dinoflagellate HABs.

\section{Eukaryotic parasites, feedback and food web models}

For over $100 \mathrm{yr}$, there has been a growing recognition of the importance of dinoflagellate parasites 
(Coats 1999), and in general there has been a recent appreciation of the potential impact of parasites on phytoplankton in a range of marine and freshwater environments (Ibelings et al. 2004, Park et al. 2004). As illustrated in this study, parasites such as Amoebophrya sp. may prevent dinoflagellate blooms, including those of toxic dinoflagellates, and ultimately may provide a sufficient pressure to induce a regimeshift (Lees et al. 2006) in the system, leading to removal of the HAB species. Ciliates such as tintinnids may also be parasitized by a species related to Amoebophrya sp. (Coats et al. 1994). If this were to occur in our proposed food web (Fig. 3), then we might expect a cascade whereby top-down control on the dinoflagellates and microphytoplankton would be removed, allowing their populations to approach carrying capacities, potentially resulting in very different population dynamics. There has been a recent trend to place viruses into pelagic food web models (e.g. Singh et al. 2004), and, in general, there has been a recognition that parasites must be incorporated into food web models (Marcogliese \& Cone 1997). Our study extends this parasite-oriented development of models by indicating that parasites of dinoflagellates should be included in models of plankton population dynamics. Perhaps of greater importance is a recognition that, in general, eukaryotic parasites should be considered in microbial food web models.

Acknowledgements. Financial supported for L.G. and A.C. was from the ANR 'Aquaparadox'. We also thank the University of Liverpool Quantitative Biology III class of 2007 and 3 anonymous reviewers for their comments.

\section{LITERATURE CITED}

Andersen P, Sørensen HM (1986) Population dynamics and trophic coupling in pelagic microorganisms in eutrophic coastal waters. Mar Ecol Prog Ser 33:99-109

Anderson RM, May RM (1980) Infectious diseases and population cycles of forest insects. Science 210:658-661

Anderson RM, May RM (1981) The population dynamics of microparasites and their vertebrate hosts. Phil Trans R Soc Lond 210:658-661

Anderson DM, Gilbert PM, Burkholder JM (2002) Harmful algal blooms and eutrophication: nutrient sources, composition, and consequences. Estuaries 25:704-726

Bissinger JE, Montagnes DJS, Sharples J, Atkinson D (2008) Predicting marine phytoplankton maximum growth rates from temperature: improving on the Eppley curve using quantile regression. Limnol Oceanogr 53:487-493

Brussaard CPD (2004) Viral control of phytoplankton populations - a review. J Eukaryot Microbiol 51:125-138

Burkholder JM (1998) Implications of harmful microalgae and heterotrophic dinoflagellates in management of sustainable marine fisheries. Ecol Appl 8:S37-S62

Cachon J (1964) Contribution à l'étude des péridiniens parasites. Cytologie, cycles évolutifs. Ann Sci Nat Zool 6:1-158

Cachon J, Cachon M (1987) Parasitic dinoflagellates. In:
Taylor FJR (ed) The biology of dinoflagellates. Blackwell Scientific, Oxford, p 571-610

Calbet A, Vaqué D, Felipe J, Vila M, Montserrat S, Alcaraz M, Estrada M (2003) Relative grazing impact of microzooplankton and mesozooplankton on a bloom of the toxic dinoflagellate Alexandrium minutum. Mar Ecol Prog Ser 259:303-309

Chattopadhyay J, Pal S (2002) Viral infection on phytoplankton-zooplankton system - a mathematical model. Ecol Model 151:15-28

> Coats DW (1999) Parasitic life styles of marine dinoflagellates. J Eukaryot Microbiol 46:402-409

Coats DW, Park MG (2002) Parastism of photosynthetic dinoflagellates by three strains of Amoebophyra (Dinophyta): parasitic survival, infectivity, generation time, and host specificity. J Phycol 38:520-528

Coats DW, Bockstahler KR, Berg GM, Sniezek JH (1994) Dinoflagellate infections of Favella panamensis from two North American estuaries. Mar Biol 119:105-113

> Coats DW, Adam EJ, Gallegos CL, Hedrick S (1996) Parasitism of photosynthetic dinoflagellates in a shallow subestuary of Chesapeake Bay, USA. Aquat Microb Ecol 11:1-9

Donaghay PL, Osborn TR (1997) Toward a theory of biological-physical control of harmful algal bloom dynamics and impacts. Limnol Oceanogr 42:1283-1296

Elbrächter M (1973) Population dynamics of Ceratium in coastal waters of the Kiel Bay. Oikos 15:43-48

Flynn K, Jones KJ, Flynn KJ (1996) Comparisons among species of Alexandrium (Dinophyceae) grown in nitrogen- or phosphorus-limiting batch culture. Mar Biol 126:9-18

> Furnas MJ (1982) Growth rates of summer nanoplankton $(<10 \mu \mathrm{m})$ populations in lower Narragansett Bay, Rhode Island, USA. Mar Biol 70:105-115

Gasol JM (1994) A framwork for the assessment of top-down vs bottom-up control of heterotrophic nanoflagellate abundance. Mar Ecol Prog Ser 113:291-300

Gillooly JF (2000) Effect of body size and temperature on generation time in zooplankton. J Plankton Res 22:241-251

Gismervik I (2005) Numerical and functional responses of choreo- and oligotrich planktonic ciliates. J Plankton Res 40:163-173

> Gismervik I, Olsen Y, Vadstein O (2002) Micro- and mesozooplankton response to enhanced nutrient input-a mesocosm study. Hydrobiologia 484:75-87

- Glibert P (1997) Interactions of top-down and bottom-up control in planktonic nitrogen cycling. Hydrobiologia 363:1-12

Gómez F (2003) The toxic dinoflagellate Gymnodinium catenatum: an invader in the Mediterranean Sea. Acta Bot Croatia 62:65-72

> Griffin SL, Herzfeld M, Hamilton DP (2001) Modelling the impact of zooplankton grazing on phytoplankton biomass during a dinoflagellate bloom in the Swan River Estuary, Western Australia. Ecol Engineering 16:373-394

Hallegraeff GM (1998) Transport of toxic dinoflagellates via ships' ballast water: bioeconomic risk assessment and efficacy of possible ballast water management strategies. Mar Ecol Prog Ser 168:297-309

Hansen PJ (1989) The red tide dinoflagellate Alexandrium tamarense: effects on behaviour and growth of a tintinnid ciliate. Mar Ecol Prog Ser 53:105-116

Ibelings BW, De Bruin A, Kagami M, Rijkeboer M, Brehm M, Donk EV (2004) Host parasite interactions between freshwater phytoplankton and chytrid fungi (Chytridiomycota). J Phycol 40:437-453

Ismael AA, Khadr AM (2003) Alexandrium minutum cysts in 
sediment cores from the Eastern Harbour of Alexandria, Egypt. Oceanologia 45:721-731

Jeong HJ, Shim JH, Lee CW, Kim JS, Koh SM (1999) Growth and grazing rates of the marine planktonic ciliate Strombidinopsis sp. on red-tide and toxic dinoflagellates. J Eukaryot Microbiol 46:69-76

Johansson M, Coats DW (2002) Ciliate grazing on the parasite Amoebophrya sp. decreases infection of the red-tide dinoflagellate Akashiwo sanguine. Aquat Microb Ecol 28: 69-78

Kamiyama T (1997) Growth and grazing responses of tintinnid ciliates feeding on the toxic dinoflagellate Heterocapsa circularisquama. Mar Biol 128:509-515

Kimmance S, Atkinson D, Montagnes D (2006) Do temperature-food interactions matter? Responses of production and its components in the model heterotrophic flagellate Oxyrrhis marina. Aquat Microb Ecol 42: 63-73

Lees K, Pitois S, Scott C, Frid C, Mackinson S (2006) Characterizing regime shifts in the marine environment. Fish Fish $7: 104-127$

Lynn DH, Montagnes DJS (1991) Global production of heterotrophic marine planktonic ciliates. In: Reid PC, Turley CM, Burkill PH (eds) Protozoa and their role in marine processes. NATO ASI Series, Vol G25. Springer Verlag, New York, p 281-307

Maguer JF, Wafar M, Madec C, Morin P, Erard-Le Denn E (2004) Nitrogen and phosphorus requirements of an Alexandrium minutum bloom in the Penzé Estuary, France. Limnol Oceanogr 49:1108-1114

Marcogliese DJ, Cone DK (1997) Food webs: a plea for parasites. Trends Ecol Evol 12:320-325

Montagnes DJS (1996) Growth responses of planktonic ciliates in the genera Strobilidium and Strombidium. Mar Ecol Prog Ser 130:241-254

Montagnes DJS, Lessard EJ (1999) Population dynamics of the marine planktonic ciliate Strombidinopsis multiauris: its potential to control phytoplankton blooms. Aquat Microb Ecol 20:167-181

Montagnes DJS, Berges JA, Harrison PJ, Taylor FJR (1994) Estimating carbon, nitrogen, protein, and chlorophyll a from cell volume in marine phytoplankton. Limnol Oceanogr 39:1044-1060

Montagnes DJS, Kimmance SA, Atkinson D (2003) Using $Q_{10}$ : can growth rates increase linearly with temperature? Aquat Microb Ecol 32:307-313

Nagasaki K, Tomaru Y, Shirai Y, Takao Y, Mizumoto H (2006) Dinoflagellate-infecting viruses. J Mar Biol Assoc UK 86:469-474

> Park MG, Cooney SK, Yih W, Coats DW (2002) Effects of two strains of the parasitic dinoflagellate Amoebophyra on growth, photosynthesis, light absorption, and quantum yield of bloom-forming dinoflagellates. Mar Ecol Prog Ser 227:281-292

Park MG, Yih W, Coats DW (2004) Parasites and phytoplankton, with special emphasis on dinoflagellate infections. J Eukaryot Microbiol 51:145-155

Raymont JEG (1980) Plankton and productivity in the oceans, 2nd edn, Vol 1. Phytoplankton. Pergamon Press, Oxford

Rosetta CH, McManus GB (2003) Feeding by ciliates on two harmful algal bloom species, Prymnesium parvum and Prorocentrum minimum. Harmful Algae 2:109-126

Shumway SE (1990) A review of the effects of algal blooms on shellfish and aquaculture. J World Aquacult Soc 21: 65-104

Singh BK, Chattopadhyay J, Sinha S (2004) The role of virus infection in a simple phytoplankton zooplankton system. J Theor Biol 231:153-166

Smayda TJ (1997) Harmful algal blooms: their ecophysiology and general relevance to phytoplankton blooms in the sea. Limnol Oceanogr 42:1137-1153

Stoecker DK, Evans GT (1985) Effects of protozoan herbivory and carnivory in a microplankton food web. Mar Ecol Prog Ser 25:159-167

Strom S (2002) Novel interactions between phytoplankton and microzooplankton: their influence on the coupling between growth and grazing rates in the sea. Hydrobiologia 480:41-54

Turchin P (2003). Complex population dynamics: a theoretical empirical synthesis. Princeton University, Princeton, NJ

Turner JT, Tester PA (1997) Toxic marine phytoplankton, zooplankton grazers, and pelagic food webs. Limnol Oceanogr 42:1203-1214

Yih W, Coats DW (2000) Infection of Gymnodinium sanguineum by the dinoflagellate Amoebophrya sp.: effect of nutrient environment on parasite generation time, reproduction, and infectivity. J Eukaryot Microbiol 47:504-510 
Appendix 1. Information on how parameters and state variables were obtained, beyond details presented in the text and in Table 1

Dinoflagellate, microplankton, and nanoplankton carrying capacities $(K)$ were based on estuarine waters experiencing pulses on the order of 100 to $200 \mu \mathrm{M}$ dissolved available nitrogen, all of the nitrogen entering the primary producers, and sizespecific phytoplankton nitrogen levels as described in Montagnes et al. (1994); we also assumed that the nanoplankton, being an order of magnitude smaller, contained 3 orders of magnitude less nitrogen per cell.

Dinoflagellate mortality rate due to infection $(\alpha)$ was determined from data of Coats \& Park (2002), who provide a range of estimates of parasite intracellular times for Amoebophyra sp. in 3 dinoflagellate hosts, ranging from $\sim 35$ to $60 \mathrm{~h}$. These were then converted to per day rates $\left(0.4\right.$ to $\left.0.7 \mathrm{~d}^{-1}\right)$, and temperature corrected from $20^{\circ} \mathrm{C}$ to our standard $18^{\circ} \mathrm{C}$, assuming a $Q_{10}$ of $2\left(0.35\right.$ to $\left.0.6 \mathrm{~d}^{-1}\right)$. Note, Yih \& Coats (2000) found similar times ( 45 to $55 \mathrm{~h}$ ) for Amoebophyra sp. infecting Gymnodinium sanguineum, under a range of nutrient conditions, at $20^{\circ} \mathrm{C}$.

Parasite development rate $\left(\alpha^{\prime}\right)$, i.e. the inverse of the time needed for a parasite to transform from the vermiform stage to dinospores (Fig. 1) was determined from data of Coats \& Park (2002); they provided a range of estimates of total parasite generation time (time required to infect host, plus time spent in the host, plus extracellular maturation time) for Amoebophyra sp. in 3 dinoflagellate hosts, ranging from $\sim 60$ to $70 \mathrm{~h}$. They also provide values of the time spent in the host (see previous paragraph) and from their Fig. 4 (op. cit.) we determined the time required to infect a host as $\sim 10 \mathrm{~h}$. From these we calculated the extracellular maturation time as being between 5 and $10 \mathrm{~h}$. Temperature correcting this value (see above), we obtained a daily rate of 2 to $4 \mathrm{~d}^{-1}$.

Number of parasites released per host $(\lambda)$ was estimated as 100 to 400, based on data on Amoebophyra sp. parasitizing Gymnodinium sanguineum, under a range of nutrient conditions (Yih \& Coats 2000).

Parasite mortality rate $\left(r_{\mathrm{p}}\right)$ was determined from estimates established for Amoebophyra sp. parasitizing 3 dinoflagellate hosts, and ranged from -1.0 to $-0.26 \mathrm{~d}^{-1}$ at $20^{\circ} \mathrm{C}$, which was temperature corrected to $18^{\circ} \mathrm{C}$, assuming a $Q_{10}$ of 2 .

Parasite transmission rate $(\beta)$ is notoriously difficult to estimate. However, Coats \& Park (2002) present experimental data wherein an initial number of uninfected dinoflagellates $\left(10^{3} \mathrm{ml}^{-1}\right)$ was challenged for $36 \mathrm{~h}$ with a known number of parasite dinospores (expressed as the dinospore:host ratio) within $10 \mathrm{ml}$; prevalence of infection $(p)$ was determined and Eq. (A1) was fitted to the data,

$$
p=I_{\mathrm{MAX}}\left(1-\mathrm{e}^{-b x}\right)
$$

where $I_{\mathrm{MAX}}$ is the maximum observed infection level and $b=a / I_{\mathrm{MAX}}$, where $a$ is the slope of the initial linear portion of the fitted curve and $x$ is the dinospore:host ratio. From this, Coats \& Park (2002) estimated $a=66 \%$ and $I_{\mathrm{MAX}}=98.2 \%$ for Amoebophyra sanguinea, which can be used to calculate the prevalence of infection $(p)$ at all dinospore:host ratios $(x)$.

Assuming no dinospore or host reproduction or mortality throughout this short experiment, the dynamics of uninfected host cells $\left(D_{\mathrm{u}}\right)$, infected host cells $\left(D_{\mathrm{i}}\right)$, and parasite spores $(P)$ can be modelled by Eqs. (A2) to (A4):

$$
\begin{gathered}
\frac{\mathrm{d} D_{\mathrm{u}}}{\mathrm{d} t}=-\beta D_{\mathrm{u}} P \\
\frac{\mathrm{d} D_{\mathrm{i}}}{\mathrm{d} t}=\beta D_{\mathrm{u}} P \\
\frac{\mathrm{d} P}{\mathrm{~d} t}=-\beta D_{\mathrm{u}} P
\end{gathered}
$$

Note that, as with standard host-parasite models (Anderson \& May 1980, 1981), this framework assumes that transmission increases linearly with host concentration. However, in the experiments of Coats \& Park (2002), host concentration was kept constant, meaning it is not possible to determine how transmission scales by host concentration. For simplicity, we therefore make the standard assumption of a linear relationship, but acknowledge that this is an approximation; clearly, detailed experiments are needed to quantify the functional form of the parasite transmission relationship before more accurate projections can be made.

In the model given by Eqs. (A2) to (A4), the initial number of $D_{\mathrm{u}}\left(10^{4}\right.$ cells $\left.\mathrm{ml}^{-1}\right), D_{\mathrm{i}}(0)$ and $P$ (given by the initial dinospore:host ratio) are known, as is the final prevalence (calculated from Eq. A1). Solving Eqs. (A2) to (A4) for the expected prevalence $\left(D_{\mathrm{i}} /\left[D_{\mathrm{u}}+D_{\mathrm{i}}\right]\right)$ at the end of the experiment (i.e. $\left.36 \mathrm{~h}\right)$ and solving for $\beta$ we obtain Eq. (A5):

$$
\beta=\frac{\ln \left[1+\frac{\ln (1-p) N}{P_{0}}\right]}{N t} \times 24 / 100
$$

where $N$ is the initial number of hosts in the experiment $\left(10^{4} \mathrm{ml}^{-1}\right), P_{0}$ is the initial number of dinospores (which is given by $x N$, where $x$ is the dinospore:host ratio) and $t$ is time $(36 \mathrm{~h})$. This expression is multiplied by 24 to convert from $\mathrm{h}^{-1}$ to $\mathrm{d}^{-1}$ and divided by 100 to convert to $\mathrm{l}^{-1}$. Performing this calculation for various dinospore:host ratio values $(x)$ presented in Coats \& Park (2002) provides an average estimate for $\beta$ of $4.2 \times 10^{-7} \mathrm{~d}^{-1} \mathrm{l}^{-1}$, with a range between $7.06 \times 10^{-8}$ and $7.15 \times 10^{-7} \mathrm{~d}^{-1} \mathrm{l}^{-1}$.

Microplankton maximum growth rate $\left(r_{\mathrm{m}}\right)$ was not necessarily the maximum potential growth of any phytoplankter. However, the rate chosen was appropriate for dinoflagellates, allows competition, and is well within the boundaries of this size class (see Bissinger et al. 2008) 